\title{
EFFECTS OF DIFFERENT FORMS OF PRACTICING A SPORT ON ATHLETES' NERVE FUNCTION
}

EFEITOS DE DIFERENTES MODOS DE PRÁTICA DE UM ESPORTENO DESEMPENHO NEURAL DE ATLETAS

EFECTOS DEDIFERENTES MODOS DEPRÁCTICA DE UN DEPORTE EN EL DESEMPEÑO NEURAL DEATLETAS

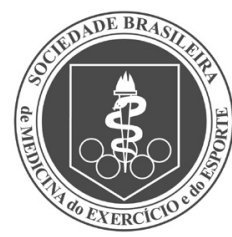

Original Article ARTIGO ORIGINAL Artículo Original
Xizhong Song 1 (D)
(Physical Education Professional)

1. Xijing University, Xi'an, China

Correspondence:

Xizhong Song

Xi'an, China. 710123

XizhongSong9@163.com

\begin{abstract}
Introduction: Poor reaction time can cause irritability, easier distractions, and interfere with normal activities that require concentration. Objective: To study the impact of simulated hypoxic training on the immune system of female middle- and long-distance runners. Methods: Observation of 50 female middle- and long-distance runners living high and training low (HiHiLo) in regard to changes in CD3+, CD4+, CD8+, NK cells and NKT cells during the process of living low and training high (LoHi). Research indicates: HiHiLo training does have a significant effect on these indicators to enhance the antioxidant capacity of the brain and nervous system. Results: Living high and training low (HiHiLo) can improve the excitability of the nervous system of long-distance endurance athletes and has a very significant impact on the stability of the nervous system. This improves cardiopulmonary function under hypoxic conditions and has a role in promoting the ability to mobilize the skeletal muscles. Conclusions: It has been proved that different forms of exercise can effectively improve the athlete's nervous response. Level of evidence Il; Therapeutic studies - investigation of treatment results.
\end{abstract}

Keywords: Sports; Huneke Neural Therapy; Human Experimentation.

\section{RESUMO}

Introdução: Um tempo de reação precário pode levar a irritabilidade, falta de concentração, e interferir em atividades diárias que exigem raciocínio. Objetivo: Estudar o impacto de treinamento hipóxico simulado no sistema imune de corredoras de média e longa distância. Métodos: Observação de 50 corredoras de média e longa distância que vivem em elevadas altitudes e treinam em baixas altitudes (HiHilo) quanto a mudanças em CD3+, CD4+, CD8+, células NK e NKT, durante o processo de viver em regiões de baixa altitude e treinar em regiões de alta atitude (LoHi). A pesquisa indica queo treino HiHilo tem um efeito significativo nesses indicadores no que diz respeito ao aumento da capacidade antioxidante do cérebro e do sistema nervoso. Resultados: O treino HiHiLo pode aumentar a excitação do sistema nervoso de atletas de resistência e longa distância, e tem um impacto muito significativo na estabilidade do sistema nervoso. Isso traz melhorias à função cardiopulmonar em condições de hipóxia e age de modo a promover a habilidade de movimentar os músculos esqueléticos. Conclusões: Foi provado que diferentes tipos de exercício podem efetivamente aprimorar a resposta nervosa de atletas. Nível de evidência ll; Estudos terapêuticos - investigação de resultados de tratamento.

Descritores: Esportes; Anestesia Local; Experimentação Humana.

\section{RESUMEN}

Introducción: Un tiempo de reacción precario puede causar irritabilidad, falta de concentración e interferir en actividades diarias que exigen raciocinio. Objetivo: Estudiar el impacto de entrenamiento hipóxico simulado en el sistema inmune de corredores de media y larga distancia. Métodos: Observación de 50 corredores de media y larga distancia que viven en altitudes elevadas y entrenan en altitudes bajas (HiHiLo) en relación con los cambios en las células CD3+, CD4+, CD8+, NKy NKT durante el proceso de vivir en regiones de baja altitud y entrenar en regiones de alta actitud (LoHi). La investigación indica que el entrenamiento HiHiLo tiene un efecto significativo sobre estos indicadores en lo que respecta al aumento de la capacidad antioxidante del cerebro y del sistema nervioso. Resultados: El entrenamiento HiHiLo puede aumentar la excitación del sistema nervioso de atletas de resistencia y larga distancia y tiene un impacto significativo en la estabilidad del sistema nervioso. Esto aporta mejorías en la función cardiopulmonar en condiciones de hipoxia y actúa favoreciendo en la capacidad de movimiento de los músculos esqueléticos. Conclusiones: Fue probado que diferentes tipos de ejercicio pueden efectivamente mejorar la respuesta nerviosa de atletas. Nivel de evidencia ll; Estudios terapéuticos - investigación de resultados de tratamiento.

Descriptores: Deportes; Anestesia Local; Experimentación humana.

\section{INTRODUCTION}

Many results have been achieved in domestic and foreign research on the impact of reaction ability on people, the study found: Poor reaction ability can cause irritability, distract people, interfere with normal thinking activities. For this effect of noise, people can be relieved by certain self-psychological hints, the degree of mitigation varies with the stability of people's psychological regulation. In sports training and competition, it is also one of the important factors that cause abnormal 
reactions and movements of athletes and affect athlete performance.' Long-distance running is a skill-led competitive event, has a fast movement rate, features such as diversification of combined movements, its offensive and counterattack scoring opportunities are fleeting, therefore, athletes are required to maintain a high degree of attention at all times during the competition, try to eliminate the influence of external noise, shorten the reaction time, accurately judge the opponent's offensive intention at any time and make appropriate offensive and defensive actions. ${ }^{2-3}$ Based on, by studying the impact of hypoxic training on the immune system of middle- and long-distance runners, we have a more comprehensive understanding of the advantages and disadvantages of hypoxic training for middle- and long-distance runners, provide a basis for middle and long-distance runners to better choose hypoxic training methods.

\section{METHOD}

\section{Research objects}

There are a total of 50 women middle and long distance runners, athletes are randomly divided into experimental group and control group, 30 people stationed in the hypoxic chamber, 20 people did not enter the hypoxic chamber, average age $(19.35+2.479)$ years old, the athlete level is national level 1 and above. There is no age before entering, the difference in exercise technique and level, the exercise load and other exercise conditions during the entry process are the same.

\section{Experimental instruments and experimental materials}

The experimental instrument is an IBM computer, the display is an IBM 15-inch flat panel display, the experimental materials used the BTL-QZ-1 temperament testing system developed by Professor Liang Chengmou. ${ }^{4}$ The test uses Visual $\mathrm{C}++6.0$ language programming software, the recorded response time results can be accurate to milliseconds, develop a temperament test system with different reaction tasks as the core. The system has obvious project characteristics in the neural response classification of professional athletes, it has good reliability and validity. ${ }^{5}$

\section{Experimental protocol}

This experiment uses a single-factor between-group pre- and post-test experimental design (see Table 1). The pre-test and post-test time are divided into October 19-20, 2004, and November 16-17, 2004, that is, 1 2 days before entering the hypoxic chamber and 1 2 days after leaving the hypoxic chamber. Each test time per person is about 30 minutes.

\section{Data statistical processing}

All data uses Excel-2003 to manage data on IBM-R51 computer, SPSS11.5forwindows system statistical software for processing, the data are expressed as mean \pm standard deviation, the significance standard of $T$ test is $P<0.05{ }^{6}$

\section{RESULTS}

In order to further examine the situation of the two groups of athletes before and after the experiment at five different reaction times, using independent sample T test, the results are shown in Table 2. The comparison results in Table 2 show that, in addition to the simple reaction, the difference level reached $P<0.05$, there were no statistically significant differences in the results of other tests.

The difference between the pre-test and post-test increases in neurological response between the experimental group and the control group can be found (Table 3), in 5 different types of reaction time tests, the improvement of the experimental group was significantly higher than that of the control group. Among them, the simple reaction shows a very significant difference, that is, $P<0.01$, there is a significant difference
Table 1. Pre- and post-test design of the experimental group and control group of athletes.

\begin{tabular}{c|c|c|c|c}
\hline Experiment grouping & Pre-test & $\begin{array}{c}\text { Experimental } \\
\text { treatment }\end{array}$ & Post-test & $\begin{array}{c}\text { Difference } \\
\text { comparison }\end{array}$ \\
\hline Test group & Y pretest 1 & $X$ & Y post test 1 & $\begin{array}{c}\text { Y pre-test 1-Y } \\
\text { post-test 1 }\end{array}$ \\
\hline Control group & Y pretest 2 & - & Y post test 2 & $\begin{array}{c}\text { Y pre-test 2-Y } \\
\text { post-test 2 }\end{array}$ \\
\hline
\end{tabular}

Table 2. Comparison of the scores of the two groups before and after the experiment in the delicate test of various neural responses.

\begin{tabular}{c|c|c|c|c}
\hline & $\begin{array}{c}\text { Test group } \\
(\mathbf{n = 3 0 )}\end{array}$ & $\begin{array}{c}\text { Control group } \\
(\mathbf{n = 2 0 )}\end{array}$ & $\mathbf{1}$ & $\begin{array}{c}\text { sig. } \\
(\mathbf{2} \text { - tailed) }\end{array}$ \\
\hline $\begin{array}{c}\text { Simple response } \\
\text { time/ms }\end{array}$ & $315.000 \pm 80.994$ & $314.000 \pm 14.142$ & 0.017 & 0.987 \\
\cline { 2 - 5 } & $291.875 \pm 48.596$ & $342.333 \pm 35.517$ & -2.244 & 0.044 \\
\hline $\begin{array}{c}\text { Two stimuli complex } \\
\text { response time/ms }\end{array}$ & $416.857 \pm 61.564$ & $459.000 \pm 14.142$ & -0.918 & 0.389 \\
\cline { 2 - 5 } & $411.875 \pm 49.715$ & $464.667 \pm 46.341$ & -2.044 & 0.065 \\
\hline $\begin{array}{c}\text { Second stimulus } \\
\text { discrimination } \\
\text { reaction time/ms }\end{array}$ & $372.286 \pm 53.128$ & $401.500 \pm 7.778$ & -0.739 & 0.484 \\
\cline { 2 - 5 } & $356.125 \pm 42.565$ & $412.833 \pm 63.926$ & -1.882 & 0.096 \\
\hline $\begin{array}{c}\text { Four stimuli complex } \\
\text { response time/ms }\end{array}$ & $629.286 \pm 68.041$ & $667.000 \pm 7.071$ & -0.746 & 0.480 \\
\cline { 2 - 5 } & $595.001 \pm 26.188$ & $602.833 \pm 108.212$ & -0.125 & 0.903 \\
\hline $\begin{array}{c}\text { Four-stimulus flip } \\
\text { response time/ms }\end{array}$ & $694.125 \pm 124.787$ & $727.500 \pm 86.974$ & -0.692 & 0.511 \\
\cline { 2 - 5 } & $675.571 \pm 94.682$ & $640.833 \pm 147.654$ & -0.713 & 0.492 \\
\hline
\end{tabular}

Table 3. Comparison of the difference between the experimental group and the control group in the test increase in neural response.

\begin{tabular}{c|c|c|c|c}
\hline & $\begin{array}{c}\text { Test group } \\
(\mathbf{n}=\mathbf{8})\end{array}$ & $\begin{array}{c}\text { Control group } \\
(\mathbf{n}=\mathbf{6})\end{array}$ & $\mathbf{1}$ & $\begin{array}{c}\text { sig. } \\
(\mathbf{2} \text { - tailed) }\end{array}$ \\
\hline $\begin{array}{c}\text { Simple response } \\
\text { time/ms }\end{array}$ & $23.125 \pm 5.878$ & $-28.333 \pm 6.649$ & 4.132 & 0.009 \\
\hline $\begin{array}{c}\text { Two stimuli complex } \\
\text { response time/ms }\end{array}$ & $4.928 \pm 3.260$ & $-5.667 \pm 3.156$ & 3.383 & 0.020 \\
\hline $\begin{array}{c}\text { Second stimulus } \\
\text { discrimination } \\
\text { reaction time/ms }\end{array}$ & $16.161 \pm 6.925$ & $11.333 \pm 4.032$ & 3.449 & 0.018 \\
\hline $\begin{array}{c}\text { Four stimuli complex } \\
\text { response time/ms }\end{array}$ & $34.286 \pm 7.897$ & $64.167 \pm 15.788$ & 2.497 & 0.055 \\
\hline $\begin{array}{c}\text { Four-stimulus flip } \\
\text { response time/ms }\end{array}$ & $18.554 \pm 5.798$ & $86.667 \pm 9.638$ & 1.976 & 0.105 \\
\hline
\end{tabular}

when the second stimulus is complicated to respond, and the second stimulus is distinguished by the response, that is, $P<0.05$. The four-stimulus flip response mainly reflects the flexibility of the nerve type, it is not reflected in this study, indicating that HiHiLo training has little effect on the flexibility of endurance athletes' nervous system.?

\section{DISCUSSION}

The comparison and analysis of the number of neural response errors before and after the two groups of experiments is based on the trade-off phenomenon of response speed and accuracy, taking reaction time as the dependent variable, a two-factor analysis of variance was performed on hypoxic conditions and the number of errors. Turn out, in addition to the significant difference in simple reaction time ( $F$ simple reaction time $=3.348$, Sig. $=0.049, \mathrm{P}<0.05$ ), there is no interaction for other items. In other words, the difference in simple reaction time between the two groups is the result of the interaction of hypoxic conditions and error rate, while the possibility of such interaction in other reaction times is very unlikely. The main effect of the difference between the two groups of simple reactions, in the analysis of variance, only hypoxic conditions reached a significant level ( $F$ hypoxic condition $=5.180$, Sig. $=0.038, P<0.05$ ), it shows that the difference between the two groups is mainly caused by hypoxic conditions. ${ }^{8}$ As for the other groups, there is no obvious 
interaction, combined with the comparison results of each reaction in Table 2, it shows that the hypoxic conditions and the error rate in this study are independent, still, neither of them has a significant effect on the changes of the other four reaction times except for the simple reaction time. This result does not fully support the endurance project in HiHiLo training mode. "If you want to improve accuracy, must slow down the exchange relationship. ${ }^{9-10}$ For a more subjective comparison, the number of neural response errors before and after the two groups of experiments was made into a line graph (Figure 1).

It is not difficult to find from Figure 1 that as the difficulty of the reaction type increases, the ratio of the mean error between the experimental group and the control group is getting larger and larger, and the rising trend of

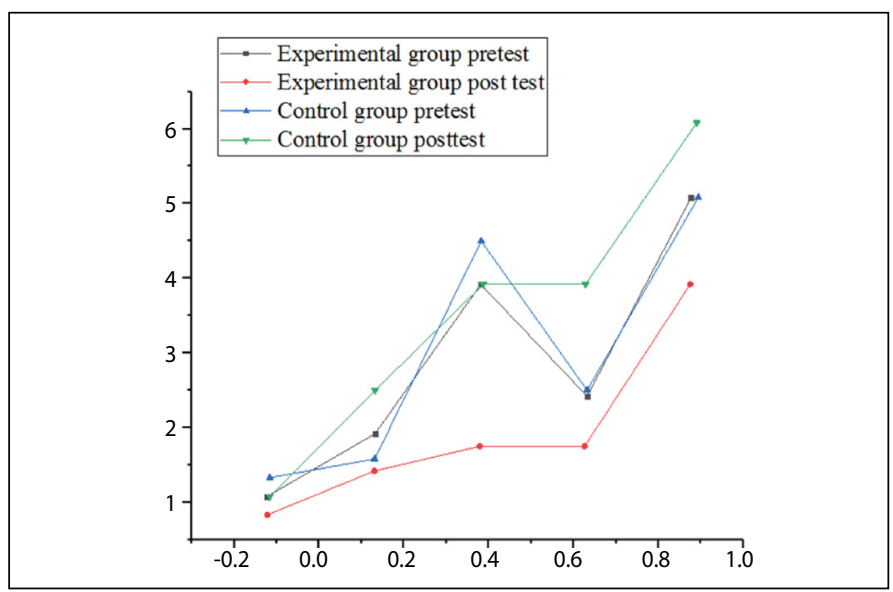

Figure 1. Comparison of the number of reaction errors before and after the two groups of experiments. the post-test broken line of the control group is much higher than that of the experimental group, finally, there is a clear difference in the latter two. It shows that the HiHiLo training mode has a certain impact on the error rate of the athlete's complex neural response, the difference in the possibility of errors in the simpler neural response types has little effect. In addition, you can also find, the pre- and post-tests of the control group showed an undulating and intertwined development with the increasing difficulty of the test, in the experimental group, the post-test error rate is always lower than that of the pre-test, it shows that HiHiLo training mode does have an impact on athletes' correct judgment ability. The reason, it can be considered that the athlete's psychological response level and cognitive behavior will change to a certain extent under hypoxic stimulation, at the same time, it has once again confirmed the relevant research and reports.

\section{CONCLUSION}

After 4 weeks of HiHiLo training, from the results of the test, athletes have significant differences in simple reaction time, there is no difference in other test scores. However, from the comparison of the increase in the test group and the control group's neural response time, the progress gap of the experimental group was significantly higher than that of the control group. Among them, there is a significant difference in the simple response time, the second stimulus complex response time, and the second stimulus discriminating response time, and the four stimulus complex response time value approaches significant, and there is also a significant level difference in the improvement in the number of response errors between the two groups.

The author declare no potential conflict of interest related to this article

AUTHORS' CONTRIBUTIONS: The author made significant contributions to this manuscript. Xizhong Song: writing and performing surgeries; data analysis and performing surgeries; article review and intellectual concept of the article.

\section{REFERENCES}

1. Yao A, Liu Y, Luo X, Liu C, Tang Y, Wang S et al. Mediation effects of different sulfur forms on solubility, uptake and accumulation of $\mathrm{Cd}$ in soil-paddy rice system induced by organic carbon and liming. Environmental Pollution. 2021;279(8):116862.

2. Gillen ZM, Jahn LE, Shoemaker ME, McKay BD, Mendez Al, Bohannon NA et al. Effects of Eccentric Preloading on Concentric Vertical Jump Performance in Youth Athletes. Journal of Applied Biomechanics. 2019;35(5):327-35.

3. Capriello T, Grimaldi MC, Cofone R, D'Aniello SD, Ferrandino I. Effects of aluminium and cadmium on hatching and swimming ability in developing zebrafish. Chemosphere. 2019;222:243-9, 2019.

4. Badarneh OS, Almehmadi FS. The effects of different noise types and mobility on error rate of digital modulation schemes over millimeter-wave Weibull fading channels. Wireless Networks. 2019;25(5):2259-68.

5. Liu Q, Wang W, Xiao W, Jing S, Zhang M, Hu Y et al. Quantifying the effects of different cold air events on latent and sensible heat fluxes of Lake Taihu. Journal of Lake Sciences. 2019;31(4):1144-56.

6. Hu D, Zhang J, Hang R, Li C, Sun Y, Yao Xet al. Effects of solid diffusion zinc treatment on corrosion behavior, antibacterial ability, and cytocompatibility of AZ31B magnesium alloy. Materials Letters. 2019;251(2):30-3.

7. Varela-Santos S, Melin P. A new modular neural network approach with fuzzy response integration for lung disease classification based on multiple objective feature optimization in chest $X$-ray images. Expert Systems with Applications. 2021;168(2):114361.

8. Vadivel R, Ali MS, Joo YH. Drive-response synchronization of uncertain Markov jump generalized neural networks with interval time varying delays via decentralized event-triggered communication scheme. Journal of the Franklin Institute. 2020;357(11):6824-57.

9. Puruncajas B, Vidal Y, Tutivén C. Vibration-Response-Only Structural Health Monitoring for Offshore Wind Turbine Jacket Foundations via Convolutional Neural Networks. Sensors. 2020;20(12):3429.

10. Mukherjee R, Chakraborty R, Dutta A. Comparison of optimization approaches (response surface methodology and artificial neural network-genetic algorithm) for a novel mixed culture approach in soybean meal fermentation. Journal of Food Process Engineering. 2019;42(5):e13124.1-10. 